\title{
Disciplinary Practices Currently Used by Teachers and Their Effects on Learner Behaviour in Primary Schools in the Hhohho Region, Kingdom of Eswatini
}

\author{
Ruth Ntombikayise Dlamini Racheal Mafumbate* \\ University of Eswatini, Department of Educational Foundations and Management, Faculty of Education
}

\begin{abstract}
The purpose of this study was to explore Teachers' Disciplinary Practices and their impact on learner behaviour in primary schools in the Hhohho region. The research employed mixed research methodology. Purposive sampling was used to select the most accessible research participants. Questionnaires, one on one interviews and observations were used as data collection instruments. Findings showed that there were several disciplinary practices that were used in primary schools by the teachers to curb students' misbehaviour. The findings also indicated that the majority of participants were using guidance and counselling to discipline students. Furthermore, the study revealed that some traditional punitive disciplinary practices are not effective in curbing students' misbehaviour in schools. Most public primary schools have embarked on the use of guidance and counselling as a measure to instil discipline. While disciplinary practices shape the overall school and classroom atmosphere, discipline affects students differently. The use of some disciplinary practices were found to contribute to poor academic performance. Considering the findings of this study, it was recommended that guidance and counselling training should be given to all teachers by the Ministry of Education and Training to help teachers get equipped with the necessary skills to handle students' issues.
\end{abstract}

Keywords: Classroom management, corporal punishment, discipline, positive discipline, punishment

DOI: $10.7176 / \mathrm{JEP} / 10-34-08$

Publication date: December $31^{\text {st }} 2019$

\section{Introduction}

The issue with learner discipline has become a worldwide epidemic problem (Emekako, 2016). Teachers are at a loss for effective methods for maintaining discipline. The lack of learner discipline can really interfere with the teaching and learning process, and if learner misconduct is not handled properly education cannot be successful ((Kourkountas \& Wolhuter, 2013). This problem manifests itself in a variety of ways, which include vandalism, truancy, smoking, disobedience, intimidation, delinquency, murder, assault, rape, theft and general violence (Moyo, Khewu \& Bayaga, 2014). Emekako (2016) has pointed out that every educator is quite aware of the need for using the classical method of reinforcing discipline to learners. The way a child is disciplined has many effects on the child's physical behavioural and mental wellbeing. Munthan, Jouhar and Abdul (2014) revealed that there are negative and positive perspectives of the different discipline practices from professionals and from the children receiving the discipline. MacNabb (2013) suggests that there are a number of discipline strategies which students perceive to be more common in classes. Some of these strategies appear to be of limited usefulness in promoting responsible student behaviour. However, there are strategies that may be more productive, resulting in less misbehaviour and more responsibility (Agesa, 2015).

The researcher has chosen this topic and not others in the education field because as a teacher, the researcher has observed children being brutally beaten up by teachers in the Hhohho region kingdom of Eswatini. This is done despite the fact that negative punishment was abolished (Save the Children, 2015).Televisions and radio talk's shows debates have been held unabated on issues of disciplinary practices. The researcher has noted that out of desperation, many teachers have continued to use harsh disciplinary practices, despite the fact that it is outlawed worldwide. Save the Children (2015) argues that harsh disciplinary practices are considered to be effective in eliminating undesirable behaviour and serves as a lesson to other pupils not to engage in similar behaviour. However, some teachers believe that harsh disciplinary practices are not effective to stop children behaving badly.

In 1974, the American Psychological Association prohibited the use of corporal punishment in schools. Thousands of children have continued to die annually because of the use of corporal punishment. Some have even become physically impaired out of injuries. Research conducted in many countries shows the severity of the physical violence students experienced while being disciplined (United Nations Educational, Scientific and Cultural Organization, 2014). Seeing brutality of children by their parents, teachers and community members, the world did not sit back watching, but stood up to enforce laws that would protect the rights of children. This law calls on government to protect children from all forms of physical or mental violence, injury or abuse. The convention on the rights of the child calls on governments to ensure that school discipline is administered in a manner that is consistent with the child's human dignity (Save the Children, 2015). 
The United Nations committee on the children's rights has emphasised that corporal punishment in the family, schools and other institutions is incompatible with the convention on the rights of the child. The United Nations committee also expressed concern at laws that allow for parents or other care givers or teachers to use any physical form of punishment on children. As a result, it has called for clear prohibition of all forms of corporal punishment (Save the Children, 2015). Western countries such as the United States of America and United Kingdom were among the first countries to abolish corporal punishment (Save the Children, 2015). Poland was the first nation to outlaw corporal punishment in schools in 1783. School corporal punishment is no longer legal in any European country. As of 2016, an estimated 128 countries have prohibited corporal punishment in schools, including all of Europe and most of South American and East Asia. Approximately 69 countries still allow for corporal punishment in schools in Asia (Gershoff, 2017).

Corporal punishment has been banned in over thirty states in the United States of America. Although the use of corporal punishment has been found to lead to serious injuries and long term damage, 22 states were still using some form of corporal punishment in 2007. Two to three million incidents of corporal punishment are estimated to occur in the schools each year, with reports of over 20,000 students seeking medical treatment (Save the Children, 2015). Moyo, Khewu and Bayaga (2014) have pointed out that in many American schools; corporal punishment is illegal even today. It is believed that students have suffered bruises, abrasions, broken bones, whiplash and brain injury. It is also believed that through corporal punishment, some learners have even died. United Nations Children's Fund (2014) revealed that in Yemen 57.7\% had been slapped on the face, beaten on the head, had their hair pulled, their hands crushed, had an object thrown at them and had been forced to stand in the sun. The Office of Civil Rights (2013) reports that 2223,190 school children in the United States received corporal punishment during the 2006-2007 school year with estimates that include up to 3 million children and 10,000 to 20,000 requiring medical treatment. Reported medical findings include abrasions, severe muscle injury, extensive hematomas, whiplash damage and others including death.

In South Africa, the use of harsh disciplinary practices was prohibited by the South African Schools Act, 1996. United Nations Children's Fund (2014) revealed that in South Africa, most teachers, students and parents accepted that beating and humiliating children is very common in schools. Richard (2016) has pointed out that there have 4,556 cases of severe corporal punishment of children in Eswatini schools over the past four years, as international news organisation reported. As recently as September 2015, a 17 year-old school pupil died after allegedly being beaten at school in Eswatini. The pupil reportedly had a seizure. In addition, Richard (2016) reported that in February 2015, the head teacher of one High School located in the Hhohho region reportedly admitted giving 15 strokes to a form 1 pupil for not wearing a neck tie properly. Furthermore, Richard (2016) has pointed out that in March 2015, a primary school teacher in one school was charged with causing grievous bodily harm after allegedly giving 200 strokes of the cane to a 12 year-old pupil on her buttocks and all over her body.

Agesa (2015) revealed that the banning of corporal punishment points to the need and importance of positive measures to ensure discipline. This is what Simatwa (2012) refers to as positive discipline. Simatwa (2012) added that positive discipline is one of the modern discipline approaches. It is the plan that was designed for educating younger individuals so that they became a mannerly, technician and responsible ones in their societies. The encouragement and mutual respect among students and adults (including teachers, parents and coaches) are the most important social skills that are learned in this approach. The teacher encourages the students for expressing their beliefs and also they are permitted to select their interests in the classrooms with positive discipline approaches. However, some teachers point out that positive discipline is preferable to corporal punishment because it is based on positive authority (Media, 2013). Bechuke (2015) revealed that the number of disciplinary actions taken by schools in response to less serious behavioural offenses has increased over time. Disciplinary practices used by teachers are crucial to achieve the objectives of teaching and learning. The major concern among researchers globally is the nature of student discipline among teachers and its effect on student behaviour in particular context.

Teachers in Eswatini are using various disciplinary practices recklessly. Teachers are failing to use effective disciplinary practices (Mussa, 2015). There is evidence that out of desperation to maintain discipline, teachers have resorted to use outlawed disciplining practice (Moyo et al., 2014). Teachers are still stuck with corporal punishment even though they were strongly warned against using it by several humanitarians and psychologists because it is against human rights, and it has side effects (Save the Children, 2015). Agesa (2015) states that the ban of corporal punishment called for the use of different kinds of disciplinary strategies, but their effectiveness in curbing future misbehaviour is still questionable. Teachers are still in a dilemma of having to find effective ways of dealing with students' misbehaviour in schools while at the same time minding about students' right. Nyang'au (2013) noted that emerging views indicated that, on one hand some educators and part of the society support the use of corporal punishment as an effective disciplinary strategy, while on the other side educational policies in the Kingdom of Eswatini ban its use in the spirit of protecting child's right. Eswatini has an article in the constitution which states that a child should not be subjected to abuse or torture or other cruel inhuman and 
degrading punishment; subject to lawful and moderate chastisement for the purpose of correction ( Constitution of Swaziland, 2015).

\section{Statement of the problem}

The Swaziland National Children Policy of 2009 provides guidelines to ensure that appropriate interventions are put in place to adequate care and protection of children in general and vulnerable in particular (Constitution of Swaziland, 2005). In most schools teachers have found themselves at crossroads as regards to the appropriate and effective disciplinary strategies to use to deal with student misbehaviour. In the Kingdom of Eswatini, the government, through embracing the United Nations Convention started moving away from using corporal punishment and replaces it with positive disciplinary practices. There is a contradiction; and an on-going debate on which disciplinary practices should be used to ensure discipline. No studies have been conducted on which disciplinary practices should be used to ensure discipline. Therefore, the major problem that will be investigated in this study focuses on the disciplinary practices currently used by teachers and their effects on learners' behaviour in primary schools in the Hhohho region, Kingdom of Eswatini.

\section{Research objectives of the study}

Specifically, the study sought to:

i. find-out which disciplinary practices currently used by teachers in primary schools in the Hhohho region; and

ii. explore the effects of disciplinary practices on the learner behaviour in primary schools in the Hhohho region.

\section{Theoretical framework}

The theoretical framework applicable to the study was the Choice theory of learner behaviour. Bechuke and Debeila (2012) revealed that the Choice theory of behaviour was developed by William Glasser (2010). Ogu (2013) indicated that Choice theory is also known as rational theory, formerly called 'Control theory'. The term Control theory posits that behaviour is central to our existence and is driven by five genetically driven needs. Choice theory states that all we do is behave, almost all behaviour is chosen, we are driven by our genes to satisfy five basic needs; survival, love and belonging, power, freedom and fun. This theory aims to find new ways to understand and explain how educators can help these learners exhibit positive behaviour by themselves through the choice that they make. Upindi, Mushaanda and Likando (2016) indicated that Glasser believes in fundamental human motivation which drives a person to a certain direction. The theory acknowledges the significance power of the need for motivating learners in schools through involving them in decision making about issues related to their discipline. The theory advocates that guidance and counselling are some of the important tools in helping learners to develop self-discipline. According to this theory, learners should be empowered to explore ways of achieving self-actualisation, self-confidence and self-enhancement. Snyder and Bub (2014) revealed that the theory acknowledges the significant power of the need for motivating learners in schools through involving them in decision making about issues related to their discipline. Choice theory principles may be applied in schools by giving learners more responsibilities, opportunities to exercise freedom, explore, argue, take risks and make decisions about the matters to which they can contribute towards improving discipline in schools. The choice theory focuses on the issue of helping learners to develop personal responsibilities, thus shifting toward a higher level of internal locus of control and self-discipline. According to this theory, learners should be empowered to explore ways of achieving self-actualisation, self-confidence and self-enhancement.

The researcher intends to adopt Choice theory in this research because the theory focuses in particular, on student behaviour and discipline. The theory states that all behaviour is an attempt by individuals to satisfy needs that are built into genetic structure of the brain, which makes it cognitive in nature (Ogu, 2013). The researcher also intends to adopt Choice theory in this research because the principles of managing discipline and modifying challenging leaner behaviour by using choice theory does not entail any form of punishment through the use of physical force with the intention of causing a learner pain, but for the purpose of correction or control the learner behaviour. As such, it is ideal as it provides answers to the main arguments against corporal punishment in schools. Choice theory strives both to extinguish the negative behaviour and at the same time teach learners how to behave acceptably (Glasser, 2010). As an educator, one needs to create the condition in which students feel a sense of belonging, have some power and control, have some freedom in the learning and schooling process and have fun. Thus, students will not be frustrated and discipline problems should be limited.

\section{Research Methodology}

The study employed a mixed research approach. Due to the fact that the researchers opted for a mixed method approach which is both qualitative and quantitative, the sampling of this study was based on purposive sampling 
approach. Purposive sampling approach was used to select the head teachers and teachers who portrayed the key characteristics or elements with the potential of yielding the right information. In this study, the participants were chosen from a specific target group whose opinions are of specific interest for the study. Purposive sampling was used to get the sample of head teachers and teachers from selected schools. This method was used because it economizes time and reliable information was obtained at a much reduced cost. Data were collected by means of a questionnaire, interviews and observation.

\section{Discussion of Findings}

\subsection{Disciplinary practices currently used by teachers in primary schools in the Hhohho region}

The findings of this study revealed that teachers in primary schools in the Hhohho region currently used suspension, guidance and counselling, manual activities, denial of privileges, corporal punishment, and parental involvement as disciplinary methods.

\section{Theme 1: Suspension}

From the study, it was reported that suspension was a disciplinary action that was administered as a consequence of a student's inappropriate behaviour, requiring that a student absented himself from classroom or from school for a specific period. A principal may suspend the misbehaving learners and ask them to come back to school after a period of time bringing along their parents. However, the participants revealed that in primary schools there were very few students who were suspended due to misbehaviour. The findings of this study also indicated that most respondents were against the use of suspension in primary schools to discipline misbehaving students. Therefore, students must not be suspended from primary schools. Sixteen head teachers (33\%) and 32 teachers $(67 \%)$ who participated in the study revealed that there were very few cases where the pupils misbehaved to a point that they should be suspended.

\section{Theme 2: Guidance and counselling}

The findings of this study indicated that the majority of participants were using guidance and counselling to discipline students. Guidance and counselling was used to help students to discover their mistakes. Guidance and counselling helped the students to be able to make decisions. Guidance and counselling promoted self- discipline and it was a form of discipline that was not harmful to the students. Counselling is the skilled and principled use of relationship that develops self- knowledge and emotional acceptance. Counselling is concerned with helping individuals to work through feelings and inner conflicts so as to improve relationships with others. The findings indicated that most respondents agreed that misbehaving students should be guided and counselled.

\section{Theme 3: Manual activities}

The study indicated that some teachers used manual activities to discipline students in their respectful schools. Manual activities did not address the misbehaviour as committed by the students. Instead, it led to building of negative attitude by the students who were punished through being assigned manual work. The main purpose of manual work was to fix the wrongdoer. As the punished student carried out the manual work in full view of other students, he or she felt demeaned and psychologically abused. The use of manual work to punish offenders lead to tension and enmity between the school and the student.

\section{Theme 4: Denied from privileges}

The study also revealed that some educators used denial of privilege to discipline students. Denial of privilege involved removing positive reinforcement for unacceptable behaviour. Findings indicated that most respondents supported the use of denial privileges to promote good behaviour amongst the students. Some educators used denial of privilege to remove positive reinforcement for unacceptable behaviour. During break time those who were misbehaving remained in the classroom for some minutes. As the others were enjoying their breakfast, the misbehaving learners remained in class. One of the participants said:

I usually use denial of privilege for misbehaving learners. For example during break time those who are misbehaving remain in the classroom for 15 minutes. As the others are enjoying their breakfast, the misbehaving learners remain in class. This kind of disciplinary practice helps because the learner makes sure that he is not misbehaving to avoid denial of her or his privilege.

\section{Theme 5: Corporal punishment}

From the study, it was reported that corporal punishment remains a disciplinary practice because it is a quick and easy method of disciplining a student. Corporal punishment is supported by the bible, in that way it is preferable to curb students' misbehaviour. The participants revealed that learning is very difficult without the use of corporal punishment because at home parents use corporal punishment to discipline the children. In that way corporal punishment was based on the Swazi culture. This investigation revealed that although the use of corporal punishment has been prohibited from use since 1996 by the Ministry of Education and Training, it is still considered a method of handling learner discipline. For example, one participant indicated that:

Corporal punishment remains a disciplinary practice, because it is a quick and easy method of disciplining a student. Corporal punishment is supported by the bible, in that 
way it preferable to curb students' misbehaviour. Learning is very difficult without the use of corporal punishment because at home parents use corporal punishment to discipline the children. In that way corporal punishment is based on the Swazi culture.

Theme 6: Parental involvement

This investigation revealed that children felt more secure and behaved better if their parents were involved in school activities. Students knew that if they misbehaved at school, at home they would be punished. Parental involvement was a good disciplinary practice because it helped the parent to know what was going on in the school concerning his or her child. Parents were needed to correct learners' behaviour. It was very difficult for teachers alone to curb students' behaviour. Parents were to be involved in every part of the education of their children, in order to take responsibility of whatever was the outcome of their children's conduct.

\subsection{Effects of disciplinary practices on the learner behaviour in schools in the Hhohho region} Theme 1: Effects of suspension on the learner behaviour

Some of the students who misbehaved actually preferred to be suspended and to be out of school. Suspension caused some of the students to leave the school forever. If a student, who was a problem was suspended, the teachers would be free from stress that was caused by a naughty student. Some students were going to school just to please their parents, otherwise they did not like schooling, and so if the teachers suspend the student, the student became very happy knowing that he or she would be away from learning. Sending students back home was like giving them a leave because the suspended students would be free from attending classes and they would be able to do whatever they wished to do. Suspension from school was used for a variety of reasons. In some cases it was administered because as a student was severely disrupting the learning environment and only the removal of the offender could allow learning to continue. Suspension from school led to the loss of valuable learning time from the student who may never catch up with the work done by others in their absence due to suspension from school. The removal of a student allowed avoidance to be meeting and convey the message to students that misbehaviour may lead to the escape from school. Suspension is the most commonly used form of discipline for serious misconduct. A principal may suspend the misbehaving learner and ask them to come back to school after a period of time bringing along their parents. In this regard, suspension from school was effective in removing a problematic student from school, providing temporary relief to frustrated school personnel and raising parental attention to their child's misconduct. The findings indicated that student try by all possible means to improve their behaviour so that they did not lose their privilege.

\section{Theme 2: Effects of guidance and counselling on the learner behaviour}

The findings of this research study indicated that guidance and counselling is helping in achieving improved students behaviour because it made students to be aware of whom they were and it developed positive attitudes among learners. Counselling seeks to address and resolve problems, helps one in decision making while also assisting one to cope with helping individuals to work through feelings and inner conflicts so as to improve relationships with others. Counselling helped students to see problems and it helped the students cope with both academic and personal issues. Counselling is concerned with helping individuals to work through feelings and inner conflicts so as to improve relationships with others. Counselling develop self-knowledge, emotional acceptance and growth. Students appreciated the importance of guidance and counselling in making them aware of who they were and being able to cope with their personality deficits. Counselling by teachers helped students to see problems before they escalated and counselling by school counsellors may help students to express any underlying issues manifested through misbehaviour.

\section{Theme 3: Effects of manual activities on the learner behaviour}

This investigation revealed that the main purpose of manual work was to fix the wrongdoer. However, the findings of this study revealed that manual activities did not address the misbehaviour committed by the students. Instead it led to building of a negative attitude by the students who were punished through being assigned manual work. Manual activity was not effective in helping to improve student behaviour because as the student was punished in front of the others, he felt ashamed and psychologically abused. Manual activities were not effective towards the learners' behaviour, as a result the student end up not willing to go to school. The punished student carried out the manual work in full view of other students, he or she felt demeaned and psychologically abused. Therefore, the use of manual work to punish offenders led to tension and enmity between the school and the student resulting in deterioration of the relationship between the two parties. The respondents also revealed that assigning students to do manual activities also promote diseases like asthma.

\section{Theme 4: Effects of denial or withdrawal of privileges}

This investigation revealed that denial or withdrawal of privileges was helping to maintain acceptable student behaviour. Withdrawal of privileges helped in maintaining acceptable student behaviour because the student would feel pain as the other students were participating in other activities. In that way the punished student would make sure that the problem of misbehaving would not be repeated to avoid being punished. This strategy was effective. However, it must be applied with certain conditions for effective results to be achieved. All the 
educators supported the disciplinary practice. The findings of the study concluded that denial of privileges as a disciplinary practice helps to improve the student behaviour in primary schools in the Hhohho region.

\section{Theme 5: Effects of corporal punishment}

The use of corporal punishment inculcated a strong belief in the impressionable minds of students that force is justified to control unwanted or undesirable behaviours. This promoted the attitudes of children that use of force or aggression was an acceptable act in the society. Corporal punishment affected the cognitive development of the children. Spanking the students' buttocks or hands and doing other forms of punishment can of course hurt the children's body. If this was done more than once or twice a week, the child's growth physically, emotionally, and intellectually may be slowed down. Students who were corporally punished were very aggressive to their fellow students. Corporal punishment led to the negative effect in the brain by decreasing some of the cells, make learners to hate their teachers and parents, committing suicide and engage themselves in the use of drug abuse. One participant said "Students who are corporal punished are very aggressive. Most of them hate their teachers and they are always thinking of revenging because they are full of anger. Corporal punished students are slow learners in classroom level. Their thinking level is very slow in the classroom situation. However it makes the student to be self disciplined due to fear of the stick".

\section{Theme 6: Effects of parental involvement}

The findings of this study indicated that parental involvement helped to reduce learner misbehaviour because students were scared of their parents. This investigation revealed that children felt more secure and behaved better if their parents are involved in school activities. One participant remarked "Parental involvement is used in school D. It helps to reduce learner misbehaviour because students are scared of their parents; they know that if they misbehave at school at home they will be punished".

\section{Conclusions}

The following conclusions were drawn from the findings of the study:

Firstly, the majority of teachers and head teachers had raised various disciplinary practices currently used by teachers in primary schools in the Hhohho region. The research concluded that all public primary schools had embarked on the use of disciplinary practices after the withdrawal of corporal punishment. The disciplinary practices that the teachers were using include suspension, guidance and counselling, parental involvement, corporal punishment, denial of privileges and manual activities. Guidance and counselling is the most popularly used form of disciplinary practice while suspension is the least. The researcher observed that although use of corporal punishment had been banned in schools, teachers still used it in all the schools. Beating sticks to deal with misbehaving students were still kept in classrooms.

Secondly, the study established that while disciplinary practices shaped the overall school and classroom atmosphere, discipline affects students' population differently. The use of some disciplinary practices had been found to be damaging to academic performance, as these activities took children out of the learning environment of the school. Guidance and counselling helped in achieving improved students' behaviour. Manual activity is not effective in helping to improve student behaviour because as the student was punished in front of the others, he felt ashamed and psychologically abused. This investigation revealed that denial or withdrawal of privileges was helping to maintain acceptable student behaviour. Suspension caused some of the students to leave the school forever.

\section{Recommendations for action}

Based on the findings of this study, it is recommended that:

1. the Ministry of Education and Training should give all the teachers guidance and counselling training to be well equipped with the necessary skills to handle students' issues;

2. adequate guidance and counselling sessions should be regularly organised for the students in their respective schools by the head teachers; and

3. teachers should be able to discipline themselves to stick to the positive disciplinary practices because they somehow find themselves administering corporal punishment.

\section{References}

Agesa, R. I. (2015). Effectiveness of alternative disciplinary strategies used in secondary Schools in Starehe Division, Nairobi County, Kenya. Unpublished master's dissertation. Nairobi, Kenya: Department of Education Management, Policy and Curriculum.

Bechuke, A.L., \& Debeila, J. R. (2012). Applying Choice Theory in fostering discipline: Managing and modifying challenging learners' behaviours in South African schools. International Journal of Humanities and Social Science, 2(22): 240-253.

Bechuke, A.L. (2015). Application of Choice Theory in managing and influencing challenging learner behaviour in schools in the Ngaka Modiri Molema District. Unpublished master's dissertation. Mafikeng Campus, 
North West University. Department of Education.

Constitution of Swaziland (2005). The Swaziland Constitution. Mbabane. Macmillan.

Emekako, R. (2016). Disciplinary measures for learners in secondary schools: An evaluation of a district in the North West Province. Pakistan Journal of Social Sciences, 13: 64-72

Gershoff, Elizabeth (2017). School corporal punishment in global perspective: prevalence outcomes, and efforts at intervention. Psychology, Health and medicine 22: 224-239.

Glasser, W. (2010). Choice Theory: A new psychology of personal freedom. New York: Harper Collins.

Kourkoutas, E.E. \& Wolhuter, C.C. (2013). Handling learner discipline problems: A Psycho-social whole School Approach. Koers-Bulletin for Christian, 78 (3): 550-558.

MacNabb, A. (2013). Disciplinary practices in the elementary School setting. Trinity College, Hartford, South, South Africa. Unpublished master's dissertation. Hardford, South Africa: Department of Education.

Mason, W. (2015). Intervention strategies to decrease discipline issue in an urban pre-K-8 Public school. Unpublished master's dissertations and Doctoral studies. Department of Education.

Media, M. (2013). Positive discipline and classroom management. Centre for justice and crime prevention and the department of basic education, Pretoria, Cape Town. Unpublished master's dissertation. Pretoria, Cape Town: Department of Basic Education.

Moyo, G., Khewu., \& Bayaga, A. (2014). Disciplinary practices in schools and principles of alternative to corporal punishment. South African Journal of Education, 34 (1):1-13.

Mumthas, N.S., Jouhar, M., \& Abdul, G. (2014). Student and teacher perception of disciplinary practices: Types, reasons, consequences and alternatives. Guru Journal of Behavioural and Social Science, 2 (4): 301-308.

Mussa, L. (2015). The role of school discipline on students' academic performance in Dar Essakiam Region. University of Tanzania. Unpublished master's dissertation. Dar Essakiam, Tanzanian: Department of Education and Management. Retrieved from Lillian-Dissertation. 27-10-2015.

Nyang'au, E. (2013). Effects of disciplinary strategies on students' behaviour in public secondary schools in Matungula District, Nairobi country, Kenya. Unpublished maser's dissertation. Nairobi, Kenya: Department of Education.

O’Brennan, L., Bradshaw, C., \& Michael, J. (2014). Influence of classroom and school climate on teacher perceptions of student problem behaviour, 6(2):125-136.

Ogu, M. (2013). Rational Choice Theory: Assumptions, strengths and greatest weakness in application outside the western Militu Context: Department of Political Science and Public Administration Babcock University, Ogun State, Nigeria. Arabian Journal of Business and Management, 1(3): 9-19.

Richard, R. (2016). Swazi School "torture” Students. blog spot.com/2011/09/swazi school-tortures-students.html.

Save the children (2015). Positive discipline in everyday teaching. A Primer for Filipino Teachers Department of Education. Unpublished draft. E-net Philippines

Simatwa, E. (2012). Management of student discipline in secondary schools in Kenya. A case study of Bungoma Country. Educational research. International Research Journals, 3(2):172-182.

Snyder, A \& Bub, S. (2014). Displine and intergenerational transmission. Undergraduate students: Human Development and Family.

Swaziland Government. (2007). Education Statistics. Mbabane: Central Statistics Office.

United Nations Children's Fund (2014). Child Disciplinary Practices at Home: Evidence from a range of low and middle-income countries, NY: UNICEF.

Upindi, N., Mushaanda, J \&Likando, G. (2016). Addressing factors that contribute to indiscipline in secondary schools in Namibia: A Case Study. Unpublished master's dissertation. Nairobi, Kenya. Department of Education and Management.

Wheeler, M. (2013). Middle school teachers' perception of discipline. The Ohio State University. Unpublished Master's of Education.

Wubblong, R.E. (2007). Glasser quality School. Group Dynamics: Theory, Research and Practice, 11(4), 253-26. 